\title{
Placing of Persons in State of Intoxication to Sobering - Whether It is Task of Local Government?
}

\author{
Ainvar Rahe \\ Police and Border Guard Board, Estonia \\ ainvar.rahe@politsei.ee
}

\section{Abstract}

The Master's Thesis that is the basis of this article has been defended on 24.05.2016, in the Faculty of Law in Tartu University (with its branch seat in Tallinn).

Alcohol and its consumption is a part of culture and social communication that has been rooted in Europe in course of long time. Producing and marketing of alcohol has a significant role in economies of countries. Simultaneously, nearly everywhere where it is consumed in significant amounts, alcohol causes serious problems for both individuals and entire society.

By means of long-term, systematic prevention work and early intervention, a local government may win a healthy and vital person who would bring tax income to local municipality by working, and in high likelihood, would create added value through increase of natural growth and contributing to community.

The author compared various different legal acts, conducted interviews with experts and personally observed procedure of conveying to sobering in Sobering-up Houses Service of the Arrest House, the North Prefecture, Estonia.

The author is of the opinion that placing to sobering is a sub-type of social services and it should be dealt with by local governments.

Keywords: alcohol, consumption, placing to sobering, local governments, treatment.

\section{Introduction}

Social status of alcohol is influenced by the circumstance of the extent to which its consumption takes place, how much of it is produced in the society, how deeply its consumption has been rooted in social life and which is the social structure of 
the society [26, 22]. Economic damage caused by the excessive consumption of alcohol that by different estimations may reach up to 5 per cent of the GDP, may surpass the income produced by this sector of economy. Estonia belongs to one of the countries where alcohol is consumed the most, and, thus, damage caused by alcohol is extensive. In 2014, there were consumed 11.7 litres of absolute alcohol per person in Estonia [20, 3]. Extent of damage is magnified by the culture of consumption that enhances consuming of big amounts of alcohol at a time; due to this connection between consumption of alcohol and accidents and violence is mere. In addition, a characteristic to Estonia is extensive spread of alcohol among the youth that has serious consequences to health of the population and potential development of the society [27].

Possibilities of medicine nowadays are still moderate for solving addiction problems as effective medicinal substances for easing dependency behaviour proceeding from desire are practically missing. By progressing of the recovery process, part of medicine decreases and the main stress is laid on social-psychological takes like shaping of new attitudes, changing of lifestyle, teaching of self-control measures and coping with stress, application of alternative activities, etc. Social support network has an important role by maintaining of sober lifestyle and prevention of relapse.

Collecting a person in state of intoxication to recover from intoxication is the task of the police [35, $\$ 42]$ and in case of absence of such conditions, the person conveyed to sobering is placed to detention house of the police. In fact, in most places there is a separate cell without furnishings (the mattress is on the floor), but the main need of alcohol addicts is getting assistance during alcohol withdrawal. In detention places of the police, in most cases the available assistance is limited to tranquillisers and analgesics or calling for the emergency medical assistance. The available enabled medical assistance is not at the same level by the police officials who are responsible for observation of the detainees and who have insufficient training in part of drugs, alcohol and mental illnesses. There is a clear need for training of police officials in issues of health care, as the lack contributes to probable impossibility of assessing whether a detainee or a person conveyed to intoxication is drunk or alcohol has concealed any illness.

In connection with socio-economical changes that have already taken place in the society for some years - ageing of population, reduce of working labour, increase of the amount of people who need assistance - in the agenda there is modernisation of administrative capacity of the state as well as of local governments and reforming of activities of the public sector more economically. The state is facing the situation where novel solutions are required for maintaining the amount of public services and their level. There are 203 local governments in Estonia: 30 towns and 183 rural governments [7], administrative capacity of which is very different. Issues related to conveying persons to sobering require money. In conditions of limited resources, it is especially important to observe feasibility of the expenses to be incurred (to consider pros and cons) and to consider which logistical changes and innovations could be applied in order to achieve the optimal use, management of resources and exchange of information that would all 
secure work of the functions without a glitch and high quality of the service. Proceeding from principle of the proceedings economy, the task subject to the proceedings shall be solved correctly, within the reasonable time and at possibly low costs (to perform these operations more efficiently, by lower costs for the state, but without losing quality of service).

\section{About Alcohol in General}

Intoxicating substances, incl. alcohol, are substances influencing the central nervous system that draw forth intoxication or a state similar to intoxication. These substances influence sense organs and change important psychical functions, for example, waking, pain sensitivity, speed of response, immediate memory and attention $[28,2]$. One may become a user of addictive substances not merely by using certain substances, but by using these in a non-accepted way (for example, for gaining intoxication, for evoking zest). Epidemiologists who have tried to assess the direct death risk proceeding from alcohol, nicotine, cannabis and other drugs denote that while considering distinction between the typically consumable and lethal threshold dose and frequency of consumption of mind-altering substances, alcohol is the most dangerous intoxicating substance.

For example, in case of alcohol, in course of a typical drinking spree, more than ten per cent of lethal amount of ethanol gets into organism. On the contrary, while smoking cannabis, the amount of THC found in it, forms less than 0.01 per cent of the lethal dose. The results do not mean as though moderate consumption of alcohol would be less dangerous than for example, injecting heroin. Risks proceeding from consumption of mind-altering substances are not connected merely with exceeding of potentially lethal doses, but also with risk factors proceeding from long-term consumption and environment.

The analysis simultaneously draws attention to circumstance that tobacco and alcohol have acquired a special status on political level at the moment, even despite the fact that direct risk of death proceeding from these is higher than that from several illegal substances. Thus, it should be drawn more attention to than before to reducing of risks proceeding from consumption of alcohol and tobacco [28].

\section{Consumption of Alcohol in Estonia}

In estimation of the World Health Organisation (hereinafter - the WHO), consumption of more than 6 litres of absolute alcohol per year per inhabitant brings along serious damage to health of the population [15]. In 2014, Estonia's grown-up inhabitants (according to the international methodology at the age of 15+) consumed, calculated per person - 85.1 litres of beer, 13.1 litres of wine, 11.0 litres of strong alcohol (incl. 7.8 litres of vodka) and 16.7 litres of low-alcohol beverages (cider, mixed drinks). In calculation of absolute alcohol, it makes in total 11.7 litres of alcohol per grown-up inhabitant. 
In comparison with the worst year of Estonia's alcohol consumption - boom-time 2007, when 14.8 litres of absolute alcohol was consumed per a grown-up, decrease has been for more than 3 litres. Proportion of people who are not consuming alcohol has grown year by year. If $13 \%$ of men and $19 \%$ of women did not consume alcohol in 2007 , then in 2014, there were $17 \%$ of men and $26 \%$ of women who named themselves as nonconsumers [20,3].

Consumption of alcohol in Estonia is characterised mainly with a view of getting drunk and consumption of big amounts of alcohol at a time ("binge-drinking" or boozing) is quite widespread and accepted. Specificity of such a consumption pattern is close connection between consumption of alcohol and violence, also between violence targeted to oneself [4]. For comparison may be brought the so-called continental drinking culture where consumption of alcohol is mainly related to food culture and lesser amounts are consumed at a time, connections between alcohol consumption and violence are loose and injuries caused by alcohol are smaller [9].

Alcohol consumption of the Estonian inhabitants is bigger than that of its northern neighbours. In 2014, there were consumed 11.2 litres in Finland, in Denmark 10.5 litres, in Sweden - 9.3 litres and in Norway - 7.8 litres of absolute alcohol per grown-up person $[20,106]$.

Alcohol consumption of young people is worrying. Consumption of alcohol within the age group from 10 up to 24 years of age is the most important risk factor as those who have started regular alcohol consumption have higher risk of health hazard behaviour as an adult as well as for abuse of alcoholic drinks. Most children do not get drunk of strong alcohol, but of low-alcohol beverages (beer, cider, mixed drinks) that children do not consider alcoholic drinks on the basis of the researches [2, 46-48]. Under-aged offenders themselves consider negative influence of their companions and friends, consumption of alcohol, problems with studies and falling apart families as main reasons for committing breaches of law. Even $75 \%$ of young people who have ended up in juvenile committees, consider consumption of alcohol as an important reason for problematic behaviour. Among repetitive clients of the committees there are many children having no support from home, also problems like unemployment, illness, helplessness, but also violence have piled up in families of problematic children [27, 54-57].

\section{Damage to Health Caused by Alcohol}

Based on the report of the WHO, alcohol is in the third place among factors causing health damage, after high blood pressure and tobacco use. Alcohol causes ca. $10 \%$ of burden of disease of the Estonian population or roughly 40,000 lost lifeyears per year. Out of loss caused by alcohol, $99 \%$ falls on men and the main part of the burden consists of loss caused by pre-mature deaths. Pursuant to report of the WHO issued in 2012, alcohol causes $12 \%$ of female and $28 \%$ of male mortality rate in age 
group 15-64 in Estonia. Problems proceeding consumption of alcohol are usually related to alcohol addiction (incl. withdrawal effects, loss of control, social alienation), regular consumption (incl. liver cirrhosis, cognitive disorders, total more than 120 diseases and disturbances), drunken state (incl. alcohol-related crime, risk behaviour, traffic accidents, injuries, etc.). In Estonia, there is a high rate of damages caused by regular consumption as well as those by drunken state. The main diseases related to alcohol that cause loss of health of men are myocardial ischemia, liver cirrhosis and stroke. Women mostly lose living years in connection with alcohol due to liver cirrhosis, another big issue causing loss of years is the stroke and the third is breast cancer. Liver cirrhosis, because of which most years are lost, causes $23 \%$ of health losses conditioned by alcohol [5].

Therefore, it must be stated that negative effect of excessive consumption of alcohol is very big and it is dealt with the factor causing poor health at most. Decrease of inhabitants and significant loss of human resources among working-age population make interference targeted towards lessening of excessive consumption of alcohol an important tool for improving health and economic situation of the population.

\section{Damage to Economy Caused by Alcohol}

Excessive consumption of alcohol leads to serious problems at the level of an individual as well as the whole society. Extent of damage is increased by consumption culture that furthers consumption of big amounts of alcohol at a time, also in comparison, for example, with the Nordic countries, consumption of strong alcohol is bigger in Estonia (see above). All of this influences society in a negative way - crime and number of accidents increase, costs to health care rise, etc.

Based on the report "Alcohol in Europe", excise duties to state treasuries amounted to $€ 25 \mathrm{bn}$ in 2003 . The intangible costs related to damage were estimated in 2003 to be $€ 270 \mathrm{bn}$. The report does not reflect damage caused by alcohol that is expressed in child abuse and unhealthy growing environment, family violence and falling apart of families and other social phenomena. It is clear simultaneously that also these phenomena retard development of human resources and pay negative effect on social wellbeing and economic development. In basic studies of the report there was also analysed alcohol damage of the United Kingdom where it becomes evident that, for example, tangible economic damages caused by alcohol - crime, lowered productivity at a work place, injuries, illnesses, deaths, and other factors - amounted to $£ 20 \mathrm{bn}[5]$.

Alcohol attributable crime estimated to cost European police, courts and prisons $€ 15 \mathrm{bn}$ per year, as well $€ 12 \mathrm{bn}$ in crime prevention expenditure and insurance administration and $€ 6 \mathrm{bn}$ of criminal damage. The pain and suffering of crime victims has also been valued at $€ 9 \mathrm{bn}-€ 37 \mathrm{bn}$. It can be said that alcohol is responsible for $12 \%$ of male and $2 \%$ of female premature death and disability [4]. At the same time, only 8 litres is drunk in the United Kingdom, but in Estonia - 11.7 litres, thus the estimated damage is 
even bigger [28, 45-47]. Proceeding from methodology used in the air pollution health effects report [21], in this analysis the statistical monetary value of a lost human life was estimated to be a bit more than $€ 1.43$ million in 2011. Proceeding from this, statistical monetary loss related to deaths caused by excessive consumption of alcohol, was nearly $€ 2.1$ million in 2011 (Table 1) [1, 18].

Table 1. Monetary value of lives lost as a result of consumption of alcohol (in millions $€$ )

\begin{tabular}{|c|c|c|c|}
\hline Year & Men & Women & Total \\
\hline 2011 & 1616 & 442 & 2057 \\
\hline
\end{tabular}

Source: Alcohol Policy Green Book, p. 18.

International experience confirms that decrease of alcohol consumption has a positive impact to economy all together [4]. By estimating possibilities of alcohol policy, it must be admitted that alcoholic drinks are legal trade articles, production, sales and marketing of which influence economy of a country significantly. At the same time, damage caused by abusive consumption of alcohol influences the whole society, not only consumers of alcohol. Hence, alcohol cannot be observed as a regular food product and for mitigating damage accompanying consumption of alcohol, consistent action and cooperation of the public, private and third sectors are needed [26].

\section{Mitigating of Damage}

By extent of damage, alcohol differentiates from other addictive substances foremost because it is addictive substance having the biggest extent of abusers. Alcohol has also the biggest population of addicts. Why is it necessary to limit consumption of addictive substances? The gains received from consumption of addictive substances are short-term and its positive impact is perceived mostly by a consumer only. However, negative impact of consumption falls often to consumer's close people and other surrounding people.

The WHO stresses that by using reasoned strategies by limiting availability of alcohol, it would be possible to reduce excessive consumption and alcohol consumption by vulnerable groups (under-aged, excessive consumers, ea.). Connections between availability of alcohol and culture are importantly influenced by local conjuncture and culture, also spread of illicit alcohol that shall be considered by designing measures [14].

The main principles for reducing consumption of addictive substances - it must be taken into account that it is dealt with substances offering pleasure and relaxation that belong to everyday life of many people and people are often not ready to reduce their consumption or to give it up. In order to achieve changes, there would be needed an integral activity strategy that would contain the following components:

- limitation of accessibility (price politics, sales restrictions);

- enforcement and surveillance of sales and advertising restrictions; 
- improvement of accessibility of services reducing consumption;

- shaping of attitudes (disapproving attitude towards getting drunk, sale of alcohol to under-aged, etc.);

- increase of awareness (of effective policies, possible assistance services, early detection of indications of danger, etc.).

It is important to pay attention to three different target groups:

- those who have never consumed before;

- those who consume too much;

- those whose dependence has developed.

Among measures for reducing damage, there are included enhancement of responsible serving and other measures preventing getting drunk and drunken driving, earlier closing of entertainment establishments and cooperation projects between local governments and police $[1,30]$. The task of an local government is to perform mapping of regional counselling and support services in order it could create systematic overview of all regional services in the region. In some sense, small local governments are in a better position as in case of smaller community a social worker's ability to reach to all those in need is much bigger. In addition, information is moving quicker in small communities that reduces possibility that the excessive consumer would remain alone and would not get assistance [22, 42].

The situation is complicated with multi-problematic alcohol consumers. It is often dealt with an unemployed or occasionally working single person living under subsistence level whose secure social environment - family, friends, and close persons - has been lost. Depression and hopelessness that have formed in conjunction of all these aspects is often expressed in excessive consumption of alcohol. Attitudes of common citizens in relation to multi-problematic alcohol consumers are often negative, caused by their appearance and permanent drunken state. The only hope for excessive consumers, who have no close people, is a local social worker or any non-governmental organisation that could provide him or her emotional support as well as assistance in relation to treatment and counselling. By socialising multi-problematic consumers, individual approach is very important. It may often seem that dealing with multi-problematic consumers is ungrateful work. They bring only costs to society and in high probability neither treatment nor counselling (resource-intensive) would bring them back to normal life arrangement [22, 46].

Also advertising influences consumption. Marketing on alcohol is multilevel it is not merely advertising of alcohol and sale promotion, but includes also see product development, choice of market segments, to whom to target one's products, price formation and accessibility of products [12]. Alcohol is advertised via traditional mass media by means of ever-ingenious advertisements, ever more sponsorship is used, that associates manufacturers with sports and culture, also new media channels - internet, mobile marketing, etc. - are used creatively [9]. Advertising of alcohol helps to normalise consumption of it - consumption of alcohol is shown in a positive light and as part of normal life. Alcohol ads are attractive for the youth, also positive image of alcohol 
manufacturers that is created by means of sponsorship, is influencing them. Attitudes of the youth who do not consume alcohol yet, are influenced by norms of alcohol consumption in the society, also by example of their parents, friends and opinion leaders depicted in media. Positive attitudes of the youth towards alcohol ads have been correlated to more positive attitude towards consumption of alcohol, they consider consumption of alcohol socially more acceptable and they are intending to drink more alcohol when they become grown-ups [11].

The aim of content restrictions of advertising is that the ad would be informative and neutral, would not promote alcohol as a self-evident part of a party, summer evening or other life situations, would not show consumption of alcohol in a positive key nor would seduce people to consume it. Bare limitation of TV-advertising is surely not sufficient for reducing consumption. If to limit advertising, then this must be done everywhere, otherwise it will simply move from one channel to another, use of which has no restrictions.

One of the options for reducing such damage is restricting sales of alcohol to drunken persons, due to this, sale of alcohol to drunken persons is prohibited in Estonia $[32, \mathbb{S} 45]$. Similar restrictions have been enforced in many countries, and in order to increase conformity of these rules, test-purchases have been conducted in several countries (USA, Canada, Sweden, the Netherlands). There can be found different examples of procedures of test shopping in scientific literature in pubs, restaurants and other establishments dealing with resale of alcohol [19]. In Finland, the licensing authority may issue an admonition or a written warning, limit business hours or without compensation withdraw the sales licence either for a certain period or permanently. In addition, police may, impose pecuniary fine on establishment that has breached the law or on its employees [31].

Proceeding from the above-said, the role of local governments is very important. The main succourer is still a social worker who can share information about regional treatment and counselling services and coordinate support groups directed to close persons. Close cooperation of family physicians, social workers and network is important by dealing with cases. Local governments gave also important role in informing possible treatment and rehabilitation services, counselling and other support systems to addicts as well as to their close persons. Comprehensive support and assistance is especially necessary for people who experience economic difficulties in coping [22, 3-7].

\section{Alcohol Deaths}

Namely young and capable to work people perish due to injury deaths connected with alcohol and drug intoxication, for what reason investments to people as well as income from performed work are not returned to society, and the society becomes more impoverished to this extent. It is also known about the consumers of alcohol that this raises the occurrence rate of depression and suicides as by virtue of alcohol, minor mental health problems transmute into more serious ones. In the study published in 2010, it was 
found that abuse of alcohol may lead to suicides via impulsivity, lack of self-control and inability to assess the situation objectively. Alcohol may also relieve anxiety accompanying suicidal thoughts, facilitating performance of this act [25].

In the European context, Estonia is conspicuous by high rate of injury deaths and injuries - for example, in comparison with the Nordic countries, the Estonian's risk to die of injury death is 2 or 3 times higher. While studying the factors inducing directly the injury deaths among Estonia's people of 18 up to 64 years of age, it became evident that alcohol intoxication was the main reason of very serious injuries. Out of all studied victims of injury death within the age of 18 up to 64, alcohol intoxication was the leading reason of very serious injuries. Out of all studied victims of injury death within the age of 18 up to $64,65 \%$ were drunk during the fatal event. Most frequently grave intoxication was registered (58\%), medium and light intoxication were registered accordingly by $25 \%$ and $17 \%$ of deadly injured victims [17].

Excessive consumption of alcohol seriously impacts genesis of many illnesses that may not be manifested otherwise. Effects fostering genesis of alcohol-related illnesses are manifested via very different mechanisms. For example, in case of gastro-intestinal tumours, an important factor is local physical damage and in case of breast cancer, changes in hormonal balance. In addition, alcohol has an effect of facilitating growth of blood vessels, by which, for example, in case of tumours, in addition to other effects facilitating growth of tumours, also accessibility of blood distribution necessary for proliferation of tumours, is secured. In addition to chronic diseases, also serious impacts to emergence of injuries and general increased risk behaviour occur in case of alcohol as different mechanisms of self- and social control are interfered [1, 17]. In Estonia, total of 460 persons died of illnesses connected directly with alcohol, incl. 142 persons in Tallinn, in 2014 [13]. Human life is of priceless value, therefore, if the growth of excessive consumption of alcohol could be stopped, also the costs related to consumption of alcohol would decrease to the Estonian society. There would decrease a number of personal and family tragedies that are connected with injured or prematurely perished family members. Injuries (incl. intoxications) kill mostly men in their best work age.

\section{Treatment of Alcoholism}

Excessive consumption of alcohol in society is one of the most significant risks to health. In case of alcohol dependence it is possible to apply to a psychiatrist's admission in general order, but in case of addiction disorder, it is limited mostly to couple of admissions or short-term detoxications that are not sufficient for generating efficient change in behaviour and maintenance of the behaviour $[6,9]$.

Excessive consumption of alcohol is a significant risk factor for ca. 60 different health disorders [30]. Early detection of abusive consumption of alcohol enables to intervene in a timely manner and to prevent from arising of more serious damage to health. The system of counselling and treatment is only in the development stage in Estonia, 
thus placing to treatment those who have problems with excessive consumption is a complicated and costly process. However, also today there exist some possibilities how to assist the abusers as well as their family members. An opinion that the person with alcohol-problems has chosen this path himself or herself and the situation where one has fallen is a free choice of the person. In case of all illnesses, patient's own will and support of other people is substantive.

There were 9,727 persons who appealed to medical specialists or family physicians due to illnesses caused by excessive consumption alcohol in 2014, e.g. $3 \%$ less than in 2013. Most commonly there was diagnosed alcohol psychosis (in case of 3,474 patients), whereby the number of cases of alcohol psychosis has fallen constantly in last years and in 2014 it decreased nearly by $20 \%$ (in 2013 there were 4,318 cases and in $2012-4,708$ cases). Out of other illnesses connected with alcohol, doctors were visited most due to alcohol addiction disorders (1,619 patients) and due to alcoholic liver disease (1,014 patients), but also the number of the persons needing assistance because of those illnesses, decreased ( $-8 \%$ and $-21 \%$, respectively). Applying to doctors because of the third most-spread result of alcohol abuse - toxic effect of alcohol - increased in turn during the year for $26 \%$ (in 2014 - 1,062 patients, in 2013 - 845 patients) [20, 4].

\section{Placing to Sobering in Law of Estonia}

The state made up by the Constitution has no right to arbitrariness in any field and all public power must always follow the Constitution. Thus, from the Constitution there proceed firstly, the tasks of the state, but secondly, also the tasks that the state must respond to by carrying out its duties. Public tasks can be divided notionally into two: the tasks related to performing of public duties or the tasks related to connected to administration of power and provision of public services to population. It is not possible to delegate public power further in its classical sense. Such an activity would be contrary to principles of democracy, making protection of fundamental rights of citizens questionable and limiting scope of impact of political decision-making mechanism $[3,7]$. Classification of public tasks - all issues of local life are decided and arranged by local governments who are acting pursuant to law independently. Local governments can be tasked only pursuant to law or in agreement with the local government. The costs related to duties of state imposed to local governments by law are covered from the state budget [33, $\mathbb{S} 154]$.

Legislator is entitled to make any tasks of local life mandatory to a local government if it is a proportional measure considering the right to self-organisation allowed by the Constitution with a view of achieving its purpose. Governmental tasks of local governments are thus divided into local government tasks proceeding from law (also "Mandatory tasks of local governments") and other tasks (also "Voluntary tasks of local governments"), performance of which is not prescribed by law [16, 12]. Nowadays safeguarding of intra-society order and security is the task of the national law enforcement 
system. Also here is used method of financing that is characteristic to state institutions in form of budgetary means and also the allegation that performance of this system is far not free of problems, does not come as a surprise. Work of the police reaches often into the centre of attention of the public in connection with corruption scandals or incapability of the police to impede the increasing number of crimes. Simultaneously, use of the services of the police does not differ from using other public resources - the situation where there has not been created the right of ownership and its use is not limited by taking fees, leads to wastage and inefficient division of resources [8, 97]. It is not unusual at all to call the police to the spot for calming down noisy neighbours or taking down the cat from the tree, as finally maintaining of the police is still paid by the taxpayers.

The Supreme Court has handled the issue related to conveying to sobering in 2007, in the light of the Police Act that was valid in 31 July 2005 [34]. Pursuant to subsection of $15^{2}$ (1) of the Police Act that was valid at that time, an intoxicated person who due to intoxication might have presented a danger to himself or herself or to other persons or fall victim to a crime should have been taken to a medical institution, a police detention house or detention cell. In context of the named Act, the Supreme Court found that performance of the danger symbols stipulated by subsection $15^{2}(1)$ of the Police Act, presumes medium or severe degree of intoxication and proceeding from this, aggressive behaviour or noticeable coordination or orientation disorders, or inability to move. It was also explained that conveyance to sobering is a preventive measure, but simultaneously it is a measure that importantly infringes the right to liberty, application of which requires consideration of all circumstances and justification of the Protocol of conveyance to sobering $[39, \mathbb{S} 19]$. Finding of legitimate basis to conveyance to sobering is complicated due to term "alcoholic" used in clause 20 (2) 5) of the Police Act as well as within the meaning of Article $5 \mathbb{\$} 1$ of the Convention.

The European Court of Human Rights (hereinafter - the ECHR) has specified that Article $5 \mathbb{S} 1$ of the Convention should not be interpreted as only allowing the detention of "alcoholics" in the limited sense of persons in a clinical state of "alcoholism". The ECHR does not prohibit deprivation of liberty from a person who is in state of intoxication in order to limit the harm caused by alcohol to himself and the public, or to prevent dangerous behaviour after drinking [40, $\$ 34]$. At the same time, the Court has stressed that mere alcohol intake cannot be the basis for deprivation of liberty and deprivation of liberty is justified as ultima ratio measure in the situation where also other and less infringing the rights of persons measures have been considered [41, $\$ 62$ and 78]. It has been referred to indicated criteria also in national court practice [39]. The idea of the above-said discourse was that at present time, pursuant to subsection 42 (1) of the Law Enforcement Act, the police or, in the cases provided by law, another law enforcement agency may take an adult in a state of intoxication [..] to recover from the intoxication in a police house of detention or detention cell if it is unavoidable for countering a significant threat, arising from the person, to the person himself or herself or another person. 
In the version of the Police and Border Guard Board (hereinafter - the PBGB) Act that was valid until 30 June 2014 [37], section $7^{29}$ stipulated also the possibility to convey the local government's house for recovering from intoxication. Thus, in valid legislation there is missing the option to convey the persons elsewhere than to the detention place of the police. It must be taken into account that by applying this measure, the police do not act repressively, but preventively and with a view to fighting off danger.

The Imprisonment Act [34] stipulates that detention houses are custodial institutions, which are staff units of the police authority which organise the imposition of custody pending trial and detention and where persons in custody and detained persons are lodged in locked cells on a twenty-four-hour basis where constant visual or electronic surveillance of them is enabled. Section 14 of the Imprisonment Act stipulates requirement to undergo medical examination performed by a medical officer of a prison upon reception of the persons into prisons. Alas, by conducting initial control there is a big difference between prison and detention house: as detention house is a temporary place of detention, then its health care services are primary, so-to-say, first-aid-like. Thus, it can be said that all requirements regulating detention in the detention place of the police are valid in relation to placing of persons to sobering.

\section{Statistics of Placing to Sobering}

Subsequently there is presented statistics of the PBGB in part of persons conveyed to sobering.

Table 2. General statistics of the PBGB for conveying to sobering in 2011-2015

\begin{tabular}{|c|c|c|c|c|c|c|c|c|c|c|c|c|}
\hline \multirow{2}{*}{ Year } & \multicolumn{3}{|c|}{ North Prefecture } & \multicolumn{3}{c|}{ South Prefecture } & \multicolumn{3}{c|}{ East Prefecture } & \multicolumn{3}{c|}{ West Prefecture } \\
\cline { 2 - 15 } & Total & $\begin{array}{c}\text { incl. } \\
\text { women }\end{array}$ & $\begin{array}{c}\text { incl. } \\
\text { minors }\end{array}$ & Total & $\begin{array}{c}\text { incl. } \\
\text { women }\end{array}$ & $\begin{array}{c}\text { incl. } \\
\text { minors }\end{array}$ & Total & $\begin{array}{c}\text { incl. } \\
\text { women }\end{array}$ & $\begin{array}{c}\text { incl. } \\
\text { minors }\end{array}$ & Total & $\begin{array}{c}\text { incl. } \\
\text { women }\end{array}$ & $\begin{array}{c}\text { incl. } \\
\text { minors }\end{array}$ \\
\hline $2011^{*}$ & 7649 & 287 & 1601 & 6158 & n.d. & n.d. & 1606 & 82 & 2 & 3934 & 387 & 217 \\
\hline $2012^{*}$ & 6517 & 353 & 1070 & 6194 & n.d. & n.d. & 852 & 59 & 5 & 3011 & 261 & 115 \\
\hline 2013 & 4915 & 351 & 843 & 5931 & 194 & 20 & 2405 & 218 & 28 & 3055 & 271 & 163 \\
\hline 2014 & 5227 & 606 & 115 & 5423 & 356 & 55 & 2184 & 159 & 7 & 2074 & 191 & 85 \\
\hline 2015 & 5881 & 637 & 49 & 5730 & 455 & 53 & 1956 & 139 & 1 & 1965 & 202 & 46 \\
\hline Total & 30189 & 2234 & 3678 & 29436 & 1005 & 128 & 9003 & 657 & 43 & 14039 & 1312 & 626 \\
\hline
\end{tabular}

* In 2011 and 2012 there are only general data about the South Prefecture (n.d. - no date).

Source: Response letter No. 1.1-14/96-2 of the Police and Border Guard Board of 23.02.2016 to application for conducting questioning. 
At present, a special sobering house exists only in Tallinn where drunken persons are dealt with by the officials of the Sobering-up House Service of the Detention House of the North Prefecture (hereinafter - Sobering-up House of the North Prefecture) and health care professionals of the West Tallinn Central Hospital (WTCH).

During preparation of present thesis, 13 officials worked in the North sobering-up house [24], medical service is provided additionally by 8 nurses and 5 carers of the WestTallinn Central Hospital plc (hereinafter - the WTCH). In sobering-up house there are total of 40 places for sobering up (incl. two single cells) and medical block with six beds. Within the cooperation agreement, the police secured personnel required for the work of the sobering-up house and technical means, the WTCH provides medical personnel and the town of Tallinn covers the costs related to exploitation of the dwelling.

The main workload in the sobering-up house is within 4 p.m. until 4 a.m., in other times the number of persons conveyed to sobering is relatively small. Within the longer view, the load is generally higher at weekends and on paydays. In Tallinn, 1,495 persons out of all those conveyed to sobering, were homeless, e.g. $28.5 \%$. In $2015,1,990$ of all persons conveyed to sobering in Tallinn were homeless, e.g. $33.8 \%$. Thus, the number of homeless persons placed to sobering is increasing and it shows that alcohol is daily consumed by those who are in socially weaker position and also that this problem must be addressed by local governments. Compared data of the first quarter of 2015 and 2016 in Tallinn regarding persons conveyed to sobering. According to these data, the number of homeless persons has increased by 162 persons and foremost by Russian-speaking homeless people. Data of other regional centres, Tartu and Pärnu are brought out for comparison, data about Jõhvi are missing. According to these data, in Tartu there is 38 \% less persons conveyed to sobering than in Tallinn and in Pärnu it was even $82 \%$ lesser. In 2015, there was sharp increase in conveying to sobering of women in Tartu (in 2014 - 181 persons, in 2015 - 275 persons). Actually, there were two women who were conveyed to sobering in total 60 times in 2015. Thus, there was no drastic increase in number of persons. If to compare the data of the first three months of the year of 2015 and 2016 about persons being conveyed to sobering in Tallinn as well as in Tartu, then increase in number of those persons can be noticed. There is no unequivocal explanation to this change. Within the period 2011-2015, in total 16 persons conveyed to sobering died (in the brackets - the number of persons dead in sobering up houses): $2011-2$ (2), 2012 - 4 (3), 2013 - 3, 2014 - 3 (1), 2015 - 4 (2) (source: Development Department of the PBGB).

The author observed procedure of acceptance of drunken persons in Tallinn, and how general requirements of detention rooms of the police are applied in the sobering-up house, then full formalisation of a drunken person (starting from the search until entry to databases) took on average 30-40 minutes, when also the police patrol who conveyed the person was present. Patrol helped also by conveying a person to medical examination when necessary and placing to a cell afterwards. At the same time, there are no such 
rigorous rules in social work centres and procedure of reception of persons lasts on average 10 minutes (it is dealt with single cases). Taking into account that the police patrol consists usually of two officials, dealing with every drunken person starting from arrival to the scene of an event until placing to the cell, takes on average 1 hour, provided that the distances are short and the drunken person does not require prior medical examination by emergency medical staff at the scene of an event. According to the data of the PBGB, in 2015 there were conveyed in total 15,532 persons to sobering, hence the police is contributing significantly their work-time to the given activity that means in turn that lesser patrols are safeguarding security in the streets.

\section{Summary}

Social status and valuation of recreational substances differs by cultures as well as by time. Alcohol is not necessary for people as air, water and food, and no one knows whether a person is able to keep alcohol within limits. As a rule, these are health care professionals who are exposed to this issue, and they have also greater responsibility for different da mages caused to addicts of alcohol abuse, but the police is responsible for crime and issues related to this before the public. Despite that, these different areas of responsibility do not exclude each other as policies and strategies performed by health care sector and police are influencing each other. Excessive abuse of alcohol is a disease, treatment of which is a complex and long-term activity. In addition to pharmacological treatment, social environment and support of close people or social worker have extremely important role.

In the state based on the rule of law, there must be secured everyone's right to social services, e.g. to services that are based on methods of social work and that improve welfare and development of persons and groups, also their adaptation to social environment. At present, it is possible to get the service of social rehabilitation and relevant advisory service from already operating offices of local governments (for example, the Social Work Centre in Tallinn) and institutions providing services to local governments on the basis of contracts, if necessary, by the agency of social welfare departments of local governments of residence.

Local governments cannot change general restrictions stipulated by law (for example, temporal prohibition of selling alcohol from 10 p.m. until 10 a.m. - subsection $40\left(1^{1}\right)$ of the Alcohol Act). Shaping of legal restrictions at local level does not presume sturdy networking, but it is simply the process of local governments that is dependent on will of officials and politicians. In order to secure consistency necessary for manifestation of influence of activities, it is sensible to put in writing the general standpoints approved by the local government council in documents relating to organisation of rural or municipal public events. Measures of alcohol policy implemented at local level are generally efficient as specific characters are better known at local level, e.g. what is 
functioning in Tallinn, may not function at the island of Hiiumaa. It is important to mention that by implementation of a single measure merely, probability of achieving the improved situation is importantly lower than by applying several different measures jointly. The best results have shown such a local alcohol policy where the main stress is laid on toughening of restrictions on availability (especially in relation to points of sale of alcohol) and attention to local policies towards public health has been enhanced. In case of Estonia it must be surely kept in mind the circumstance that our local governments are mostly small and distances between recreational events or establishments of different local governments are very short. Thus, it would not be very wise to enforce relevant requirements by a smaller local government alone, but together with surrounding rural government and towns.

Conveying and placing of drunken persons is the task of police today and in case of absence of such conditions, the persons conveyed to sobering are placed to detention houses of the police. However, detention facilities of the police are not designed for keeping such persons who need medical support; yet it is dealt with the problem of social field. Possibilities of medical science by solving addiction problems are still moderate nowadays as effective medicaments for soothing addictive behaviour proceeding from desire for substance are practically missing. By progressing of the recovery process, part of medicine decreases and the main stress is laid on socio-psychological takes like shaping of new attitudes, changing of lifestyle, teaching of self-control measures and coping with stress, application of alternative activities, etc.

Social network has an important role in maintaining sober life-style and prevention of fall-backs. As the problem of alcohol is very multiplex, for successful coping with it there should be dealt with its medical, psychological and social sides. Clients of sobering-up houses should receive medical, social and also legal assistance, if necessary. It is a very important circumstance that clients should be dealt with also after they have sobered up. Thus, it could be concluded that in form of sobering-up houses it is dealt with sub-types of social houses the aim of which is to provide social support for the persons for possible getting rid of the addiction. There must be surely taken into account the circumstance that behaviour of drunken persons is unpredictable and, unfortunately, sometimes also aggressive and for that reason also force has to be applied in relation to the persons.

Hence, the author has reached to the viewpoint that placing to sobering is a subcategory of social services and it should be dealt with by the local governments. Beyond doubt, local governments can not undertake this task to themselves immediately as there are missing legal basis as well as resources in form of money and competent personnel. But the community-centred approach requires such a service in every local government and one of the options to provide the service is cooperation between several local governments. The town of Tallinn is a good example that existence of the will is needed first of all and it is necessary to look for solutions, not reasons why it is not possible to do something. 


\section{Reibuma stāvoklī esošas personas ievietošana atskurbtuvē - vai pašvaldības uzdevums?}

\section{Kopsavilkums}

Raksts balstīts uz magistra darbu, kas aizstāvēts 24.05.2016. Tartu Universitātes Juridiskās fakultātes filiālē Tallinā.

Alkohols un tā lietošana ir daḷa no kultūras un sociālās komunikācijas, kas ir iesakṇojusies Eiropā ilgākā laika periodā. Alkohola ražošanai un tirdzniecībai ir būtiska loma valsts ekonomikā. Vienlaikus alkohols, ja tas tiek patērēts lielos daudzumos, izraisa nopietnas problēmas gan atseviškiem indivīdiem, gan visai sabiedrībai kopumā.

Ar ilgtermiṇa, sistemātisku profilakses darbu un agrīnu iejaukšanos pašvaldība var iegūt veselu un vitālu personu, kas strādājot spēj dot nodokḷu ieñēmumus pašvaldībai, un loti iespējams, ka varētu radīt pievienoto vērtību, palielinot dabisko pieaugumu.

Autors, salīdzinot dažādus tiesību aktus, intervējot ekspertus un personīgi novērojot procedūru, kā personas tiek ievietotas atskurbtuvē Igaunijas Ziemeḷu prefektūrā, secina, ka atskurbtuves pakalpojumi ir vērtējami kā sociālo pakalpojumu apakšgrupa un tie būtu jārisina pašvaldībām.

Atslēgvārdi: alkohols, patēriṇš, ievietošana atskurbtuvē, pašvaldība, ārstēšana.

\section{References}

1. Alcohol Policy Green Book. Tallinn: Ministry of Social Affairs, 2014; 2-40.

2. Allaste, A.-A., Kobin, M. School Students and Drugs. Tallinn: Tallinn University Publishing House. 2008; 46-48

3. Altnurme A. Contractual Delegation of Public Services to the Third Sector. Tallinn: Publishing House Tänapäev, 2002.

4. Anderson, P., Baumberg, B. Alcohol in Europe. A public health perspective study. A report for the European Commission. Institute of Alcohol Studies, 2006. Available at: http://ec.europa. eu/health/archive/ph_determinants/life_style/alcohol/documents/alcohol_europe_en.pdf [accessed on 23.01.2016].

5. Anderson, P., et al. Alcohol in the European Union. Consumption, harm and policy approaches. WHO 2012. Available at: http://www.euro.who.int/en/publications/abstracts/alcohol-in-theeuropean-union.-consumption,-harm-and-policy-approaches [accessed on 20.01.2016].

6. Andresen, K., et al. Treatment of Patients with Alcohol Use Disturbance. Treatment Instructions Council, 2015, pp. 5-48. Available at: http://www.ravijuhend.ee/juhendid/ravijuhendid/alkoholitarvitamise-hairega-patsiendi-kasitlus [accessed on 11.02.2016].

7. Association of Estonian Cities. Portal of local governments. Available from: http://portaal.ell. ee/547 [accessed on 19.02.2016].

8. Benson, B. The Enterprise of Law. San Francisco, 1990, p. 97. Available at: http://www.libertarianismo.org/livros/teolbb.pdf [accessed on 28.01.2016]. 
9. Bonnie, R., O'Connell, M. E. Reducing underage drinking: a collective responsibility. National Academies Press, 2004. Available at: http://www.nap.edu/read/10729/chapter/1\#ii [accessed on 20.01.2016].

10. Britton, A., McKee, M. The positive relationship between alcohol and heart disease in eastern Europe: potential physiological mechanisms. Journal of the Royal Society of Medicine. 1998, 91(8), 402-407. Available at: http://www.ncbi.nlm.nih.gov/pmc/articles/PMC1296837/ [accessed on 15.02.2016].

11. Chen, M.-J., Grube, J. W. TV beer and soft drink advertising: what young people like and what effects? Alcoholism: Clinical and Experimental Research, 2002; 26 (6): 900-906. Available at: http://www.readcube.com/articles/10.1111\%2Fj.1530-0277.2002.tb02620.x?r3 referer=wol\&tracking_action=preview_click\&show_checkout=1\&purchase_referrer= onlinelibrary.wiley.com\&purchase_site_license [accessed on 20.01.2016].

12. Davis, R. et al. (Eds.). The role of the media in promoting and reducing tobacco use. Bethesda, MD, United States Department of Health and Human Services, National Institutes of Health, National Cancer Institute, 2008 (NCI Tobacco Control Monograph Series No. 19). Available at: http://cancercontrol.cancer.gov/brp/tcrb/monographs/19/m19_complete.pdf [accessed on 20.01.2016].

13. Deaths due to illnesses caused by alcohol by gender and county. Health statistics and health research database. Available at: http://pxweb.tai.ee/PXWeb2015/index_en.html [accessed on 17.02.2016].

14. EU strategy to support Member States in reducing alcohol-related harm. European Commission 2006. Available at:http://ec.europa.eu/health/ph_determinants/life_style/alcohol/documents/ alcohol_com_625_en.pdf [accessed on 20.01.2016].

15. Health 21. The Health for all policy framework for WHO European Region. Available at: http://www.euro.who.int/_data/assets/pdf_file/0010/98398/wa540ga199heeng.pdf?ua=1 [accessed on 21.01.2016].

16. Jõerand, S. Cooperation of Public and Private Sector by Performing Public Tasks in Units of Local Governments. Master's thesis. Tartu: University of Tartu, 2015, 12.

17. Kaasik, T., Uusküla, L. Injuries in Estonia: Spread, Results and Prevention. Tartu: NGO Neighbouring Watch Centre, 2007.

18. Lachenmeier, D., Rehm, J. Comparative risk assessment of alcohol, tobacco, cannabis and other illicit drugs using the margin of exposure approach. Scientific Reports. 2015, 5, 8126. Published in 30.01.2015. Available at: http://www.ncbi.nlm.nih.gov/pmc/articles/ PMC4311234/ [accessed on 17.02.2016].

19. Lenk, K., Toomey, T., Erickson, D. Propensity of alcohol establishments to sell to obviously intoxicated patrons. Alcoholism: Clinical and Experimental Research, 2006, (30), 1194-1199.

20. Market, consumption and damage of alcohol in Estonia: Yearbook 2015. Estonian Institute of Economic Research. Tallinn, 2015; 2-40.

21. Oiseth, O. V. Drugs and Doping and Other Health Hazard Substances. The Swedish Police Board. The Swedish Carnegie Institute. The Swedish Drug Police Officers' Union. The Estonian Police Board. Tallinn, 1999, 2.

22. Options for Application of Alcohol Policy at Local Level. Instructive material for local governments. National Institute for Health Development. 2015, 3-46. Available at: http://www. terviseinfo.ee/images/prints/Voimalused_alkoholipoliitika_rakendamiseks_juhend_2015.pdf 
23. Orru, H. et al. Effect of Ambient Air to the Health of People - Assessment of Derivations from Fine Parts within the whole Estonia. University of Tartu, 2011. Available from: http:// rahvatervis.ut.ee/bitstream/1/5081/1/Orru2011.pdf [accessed on 19.01.2016].

24. Police and Border Guard Board. Available at: https://www.politsei.ee/et/kontakt/kontaktidstruktuuri-jargi $/$ exp0 $=105519 \& \exp 1=754 \& \exp 2=1051 \&$ info $=1109$ [accessed on 12.03.2016].

25. Pompili, M. et al. Suicidal behavior and alcohol abuse. International Journal of Environmental Research and Public Health. 2010, 7 (4), pp. 1392-2143. Available at: http://www.ncbi.nlm. nih.gov/pmc/articles/PMC2872355/ [accessed on 22.01.2016].

26. Principles of National Alcohol Policy, submitted to the session of the Government of the Republic in 22 January 2009. Available at: http://rahvatervis.ut.ee/bitstream/1/4042/1/ SoM\%20VVle\%2c\%202009.pdf [accessed on 17.01.2016].

27. Rannala, I.-E., Tiko, A. Youth with behavioural difficulties and application of sanctions imposed to them in Juvenile Committees. Tallinn: Tallinn University, Ministry of Justice, 2006, 54-57.

28. Reinap, M. Economic Burden of Most Significant Behavioural Health Risks. Master's thesis. Tallinn: Tallinn University of Technology, 2009, 2-47.

29. Salaspuro, M., Kiianmaa, K., Seppä, K. Alcohol Abuse Medicine. Jyväskylä: Gumerrus Publishing House OY, 1998, 22.

30. WHO Global Status Report on Alcohol 2004. Geneva: World Health Organization; 2004. Available at: http://www.who.int/substance_abuse/publications/global_status_report_2004_ overview.pdf [accessed on 10.02.2016].

\section{Source legislation}

31. Alcohol Act (in Finnish). Consolidated version available at: http://www.finlex.fi/fi/laki/ ajantasa/1994/19941143\#L4P15 [accessed on 30.01.2016].

32. Alcohol Act. RT I 2002, 3, 7 - RT I, 01.09.2015, 1. Consolidated version available at: https:// www.riigiteataja.ee/akt/101092015001 [accessed on 01.02.2016].

33. Constitution of the Republic of Estonia. RT 1992, 26, 349 - RT I, 15.05.2015, 1. Consolidated version available at: https://www.riigiteataja.ee/akt/115052015002 [accessed on 01.02.2016].

34. Imprisonment Act. RT I 2000, 58, 376; RT I, 23.03.2015, 141. Consolidated version available at: https://www.riigiteataja.ee/akt/123032015141 [accessed on 01.02.2016].

35. Law Enforcement Act. Section 42. RT I, 22.03.2011, 4 - RT I, 23.03.2015, 4. Consolidated version available at: https://www.riigiteataja.ee/akt/101092015001 [accessed on 01.02.2016].

36. Police Act. RT 1990, 10, 113 - RT I 2004, 54, 390. Consolidated version available at: https:// www.riigiteataja.ee/akt/13093343 [accessed on 01.02.2016].

37. Police and Border Guard Act. RT I 2009, 26, 159 - RT I, 15.03.2014, 31. Consolidated version available at: https://www.riigiteataja.ee/akt/131122015028 [accessed on 01.02.2016].

\section{Used court judgments}

38. Decision of the Administrative Law Chamber of the Supreme Court No. 3-3-1-98-06, of 17.04.2007, p. 19.

39. Decision of Tartu Administrative Court No 3-10-894 of 09.03.2011.

40. European Court of Human Rights Judgement 37345/03. Kharin vs. Russia, paragraph 34.

41. European Court of Human Rights Judgement 26629/95. Witold Litwa vs. Poland, paragraphs $62,78$. 